\title{
Impurity Profiling of Amphetamine and Methamphetamine Using Gas Chromatography Mass Spectrometry (GCMS) Harmonised Methods
}

(Pemprofilan Bendasing Amfetamin dan Metamfetamin Menggunakan Kaedah

Pengharmonian Analisis Kromatografi Gas Spektrometri (GCMS))

\author{
WAN NUR SYUHAILA MAT DESA* \& DZULKIFLEE ISMAIL
}

\begin{abstract}
Impurity profiling of drug seizures is a scientific approach employed to understand drug trafficking networks thus has becoming increasingly important in criminal investigation. This paper presents the feasibility of using the Collaborative Harmonisation of Methods for the Profiling of AmphetamineType Stimulants (CHAMP) established by the European Commission authority for impurity profiling of amphetamine and methamphetamine samples. Both drugs were analysed using similar extraction procedure and analytical conditions. The impurities were extracted from an alkaline buffer solution ( $p H 8.1)$ using toluene prior to gas chromatography-mass spectrometry (GC-MS) analyses. The results showed that the reproducibility of the method for detecting amphetamine and methamphetamine ranged between 7.4-8.9 and 6.2-8.4\%RSD, respectively. Identification of impurities was performed by referencing against the available MS databases as well as to previous reported impurity profiling studies. Phenyl-2-propanone (P2P), also known as benzyl-methylketone (BMK), as well as other specific impurities such as 4-methyl-5-phenylpyrimidine, bis-(1-phynelisopropyl) amine, $N$-formylamphetamine and $N, N$-di (b-phenylisopropyl) amines were identified in the amphetamine samples, indicating Leuckart's pathway as the route of synthesis. Because P2P was also detected in the methamphetamine samples, the possible route of synthesis of the methamphetamine samples being Leuckart's, nitrostyrene synthesis or reductive amination could not be ruled out.
\end{abstract}

Keywords: Amphetamine; chromatographic profiles; impurities; mass spectrum; methamphetamine

ABSTRAK

Pemprofilan bendasing bagi rampasan dadah merupakan pendekatan saintifik yang diguna pakai bagi memahami jaringan penyeludupan dadah yang menjadi semakin penting dalam penyiasatan jenayah. Kertas ini membentangkan kebolehlaksanaan Kaedah Pengharmonian Kolaboratif untuk Pemprofilan Amfetamin (CHAMP) yang diwujudkan oleh Suruhanjaya Eropah bagi pemprofilan dadah amfetamin dan metamfetamin. Sampel telah dianalisa dengan melalui proses pengekstrakan dan analisis yang sama. Pengekstrakan bendasing dilakukan menggunakan larutan penimbal beralkali (pH8.1) dengan toluen sebelum analisis kromatografi gas-spektrometri (GC-MS) dijalankan. Kebolehulangan pengesanan yang direkodkan bagi amfetamin dan metamfetamin masing-masing ialah 7.4-8.9 dan 6.2-8.4\% RSD. Pengenalpastian bendasing telah dilakukan dengan merujuk kepada pengkalan data MS dan kajian yang telah dijalankan sebelum ini.Fenil2-propanon $(P 2 P)$ atau juga dikenali sebagai benzil-metil-keton (BMK) telah dikenal pasti dalam sampel amfetamin selain bendasing seperti 4-metil-5-fenilpirimidina,bis-(1-fenilisopropil) amina, $N$-formilamfetamina dan $N$, $N$-di (b-isopropil) amina yang menunjukkan penggunaan kaedah sintesis Leuckart. P2P telah dikesan di dalam sampel metamfetamin yang menunjukkan laluan sintesis bagi dadah ini adalah berkemungkinan Leuckart, nitrostirena atau reduktif aminasi.

Kata kunci: Amfetamin; bendasing; metamfetamin; pemprofilan kromatografi; spektrum jisim

\section{INTRODUCTION}

The abuse of synthetic drugs such as amphetamine and amphetamine type stimulants (ATS) has been a major social concern worldwide (United Nations Office on Drugs and Crime (UNODC) 2014). Being classified as ATS, amphetamine and methamphetamine are referred to as synthetic or designer drugs with well established illicit markets and increasingly popular as abusive agents (Isa et al. 2013; United Nations Office on Drugs and Crime (UNODC) 2014). It has been indicated that synthetic drugs seizures have increased globally within the last seven years with the East and South East Asia regions recorded the highest number of people treated for synthetic drug addictions, in agreement with the prevailing trend in the national data obtained from the Royal Malaysia Police (RMP) records (Hamdan et al. 2015; United Nations Office on Drugs and Crime (UNODC) 2014). In comparison to the plant based drugs (e.g. heroin, opium \& cocaine), synthetic drugs are relatively easy to manufacture using common household chemicals and solvents readily available from commercial sources such as hardware outlets and pharmacies (Abdullah et al. 2014; Baharudin et al. 2013). 
Moreover, methods of production for such drugs are readily accessible from bogus sites over the internet (Cole 2003).

Amphetamine (street name pil kuda in Malaysia) and one of its analogous, the methamphetamine (street name syabu in Malaysia), share similar chemical properties i.e. having a basic amine group linked to a benzene ring, hence grouped together as phenethylamine substances (Figure 1).

The predominant routes for synthesising amphetamine are the Leuckart's reductive amination and nitrostyrene
(2 steps reaction), involving the use of $\mathrm{P} 2 \mathrm{P}$ or BMK as the precursor (Figure 2). Other rarely encountered means of amphetamine production includes using norephedrine or norpseudoephedrine precursor (Abdullah et al. 2014; Allan \& Ely 2011; Allen \& Cantrell 1989; Stojanovska et al. 2013). On the other hand, methamphetamine is predominantly synthesised using eight synthetic routes, depending on the type of precursor available at hand. Commonly, either $\mathrm{P} 2 \mathrm{P}$ or ephedrine/pseudoephedrine is used as the precursor (Figure 3). Since every synthetic<smiles>CC(N)Cc1ccccc1</smiles>

a. Amphetamine (IUPAC 1-phenylpropan-2-amine) $\mathrm{C}_{9} \mathrm{H}_{13} \mathrm{~N} 135.206 \mathrm{~g} / \mathrm{mol}$<smiles>CNC(C)Cc1ccccc1</smiles>

b. Methylamphetamine (IUPAC (2S)-N-methyl-1-phenylpropan-2-amine) $\mathrm{C}_{10} \mathrm{H}_{15} \mathrm{~N}, 149.2328 \mathrm{~g} / \mathrm{mol}$.

FIGURE 1. Chemical structures of amphetamine (a) and methylamphetamine (b)

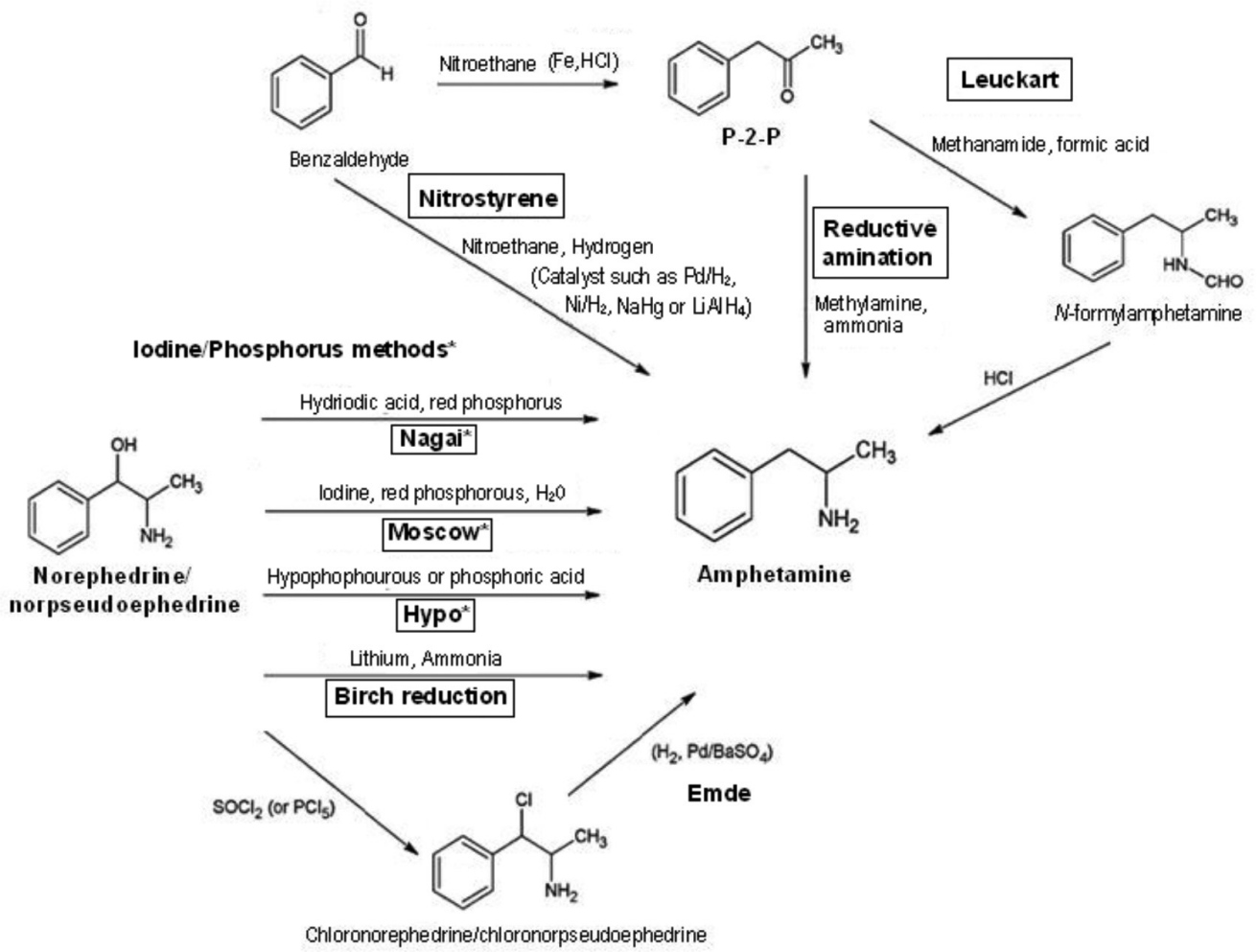

FIGURE 2. Simplified diagrammatic representation of various synthetic routes forclandestine amphetamine synthesis (Allen \& Cantrell 1989; Stojanovska et al. 2013) 


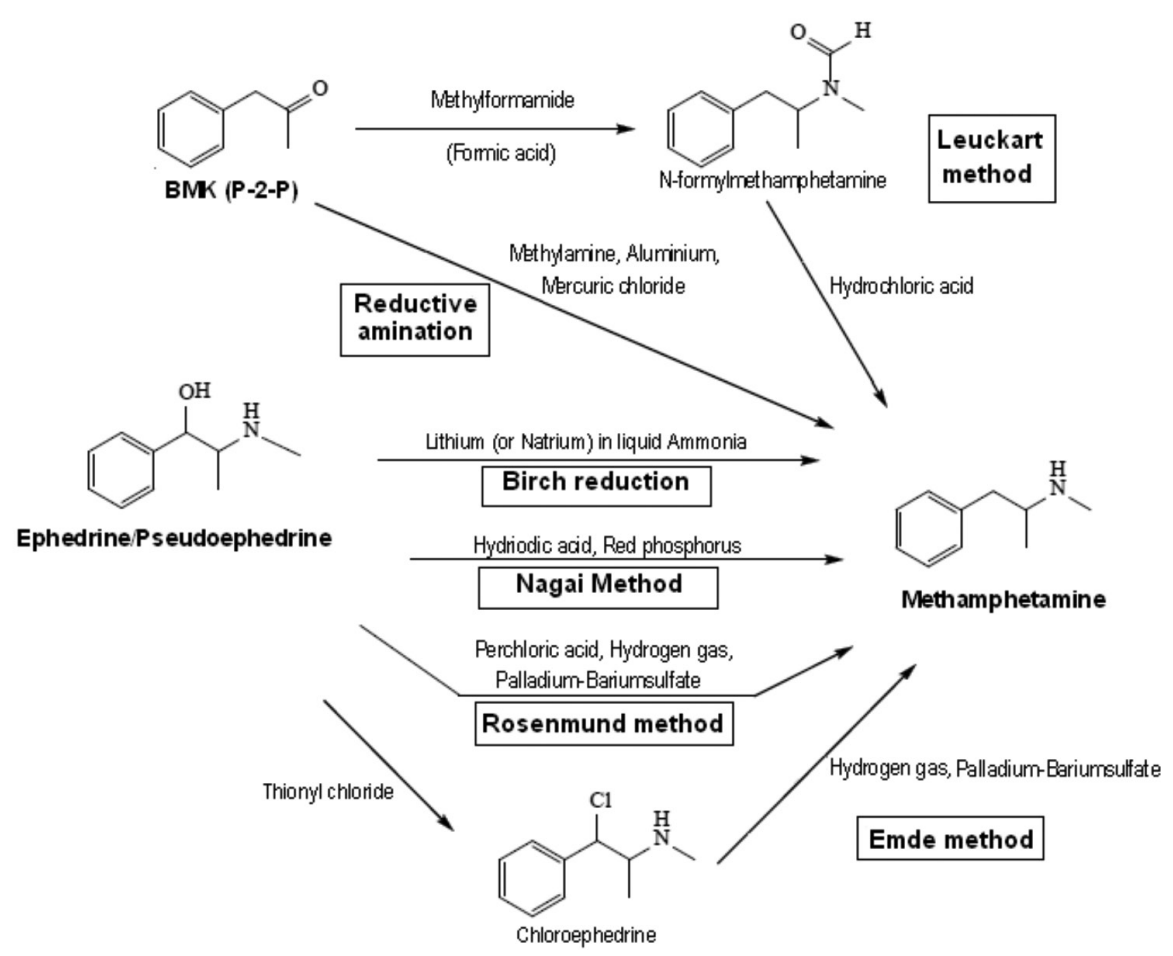

FIGURE 3. Simplified diagrammatic representation of various synthetic routes for clandestine methamphetamine synthesis (Hamdan et al. 2015; Kunalan et al. 2009)

route produces the intended final product as well as impurities and by-products, profile of impurities and byproducts may be useful in advocating the type of precursor used and hence the synthetic route (Abdullah et al. 2014; Allan \& Ely 2011; Allen \& Cantrell 1989; Stojanovska et al. 2013).

In forensic illicit drug analysis, chromatographic profiling of the drugs following extraction procedure is usually performed to obtain information about impurities in drug samples. Impurities in illicit drugs arise from reactants, by products and also intermediate contaminants which give complicated chromatographic profiles that may be useful for profiling purposes. Due to the minute abundance of these impurities, forensic drug profiling focuses on identification of impurities peaks rather than quantification of the compounds as detection and identification of target impurities are adequate to suggest possible route of synthesis. Chromatographic profiles of the organic impurities from amphetamine and methamphetamines drug seizures have been proven to offer valuable information that is useful for characterisation as well as comparing and identifying the similarities and/or differences among illicit drug seizures (Abdullah et al. 2014; Power et al. 2014; Stojanovska et al. 2013; United Nations Office on Drugs and Crime (UNODC) 2014). In addition, extensive analysis of organic and inorganic compounds in drug profiling may establish the possible link or relationship between seizures; identify the origin or source of drug supply, drug trafficking route and distribution pattern as well as possible synthesis methods (Allan \& Ely 2011).
Considering that many forensic laboratories perform drug profiling analysis using 'in-house' methods, discrimination of seizures perhaps remains limited at the national level. Given the present scenario whereby ATS drugs trafficking extends beyond regional boundaries, a harmonised method for comparative analysis of these drugs has since been suggested (Ballany et al. 2001; United Nations Office on Drugs and Crime (UNODC) 2014). In this context, the Harmonised methods for analysing amphetamine known as the Collaborative Harmonisation of Methods for the Profiling of Amphetamine-type Stimulants (CHAMP) for organic and inorganic profiling was first introduced by the European Commission authority (Aalberg et al. 2005a; Aalberg et al. 2005b; Andersson et al. 2007a, 2007b, 2007c; Lock et al. 2007). This robust method has enabled the exchange of forensic data at both national and international levels, making amphetamine drug profiling data readily comparable regardless of where the analysis is conducted therefore meaningful common link between seizures and understanding the route of trafficking can be effectively established. It would be interesting to see if the existing methods can be extended to similar type of ATS drugs for example methamphetamine so that linkages between ATS drugs are possible.

This paper aimed at demonstrating the feasibility of using the CHAMP method for impurity profiling (single extraction and chromatographic procedure) of amphetamine and methamphetamine drug seizures. Identification of impurities based on their mass spectral data to deduce the possible synthetic route is also demonstrated. 


\section{EXPERIMENTAL DETAILS}

\section{MATERIALS AND REAGENTS}

Unless stated otherwise, all chemicals used in this study were purchased from Sigma ${ }^{\circledR}$ (Darmstadt, Germany). Buffer solution (1 M) was prepared by dissolving 121.1 $\mathrm{g}$ of Trizma-base (BDH Chemicals, Poole, England) in deionised water and its final $\mathrm{pH}$ was adjusted to $8.1 \mathrm{using}$ hydrochloric acid $(\mathrm{HCl})(1 \mathrm{M})$. Once the desired $\mathrm{pH}$ was achieved, deionised water was added to the $1 \mathrm{~L}$ volumetric mark and the $\mathrm{pH}$ was measured again using a calibrated $\mathrm{pH}$ meter (Hanna Instruments, $\mathrm{pH}$ 211). Adjustment to the desired $\mathrm{pH}$ was carried out either using $\mathrm{HCl}(1 \mathrm{M})$ or sodium hydroxide $(\mathrm{NaOH})(1 \mathrm{M})$.

Four batches of amphetamine (labelled as sample A, B, C and D) and methamphetamine (labelled as E, F, G and $\mathrm{H}$ ) synthesised samples submitted to the Centre for Forensic Science, University of Strathclyde from year 2004 to 2008 were analysed in this study. Samples were in dry powder form and have been kept in sealed vials stored in a secured drug cabinet at room temperature. Following the harmonised method described by Andersson et al. (2007b), these two drugs were extracted and analysed from the respective samples. Each batch was thoroughly homogenised using a mortar and pestle prior to sampling. The homogenised sample (200 mg) was weighted, dissolved in $4 \mathrm{~mL}$ buffer solution (pH8.1) and sonicated for $10 \mathrm{~min}$. Upon completion, toluene $(200 \mathrm{~mL})$ with eicosane, $\left(\mathrm{C}_{20}\right)$ as the internal standard was added into the solution and sonicated for another $10 \mathrm{~min}$, prior to centrifugation (3000 rpm for $5 \mathrm{~min}$ ) to facilitate phase separation. The organic solvent phase was then removed and transferred into a GC vial for GC-MS analysis.

\section{INSTRUMENTATION}

Instrumental analysis was performed on a HP 6890 Gas chromatograph interfaced with HP 5973 mass spectrophotometer (MS) detector (HP Agilent, USA). The column used was an Rtx-5 capillary column $(30.0 \mathrm{~m} \times$ $0.25 \mathrm{~mm}$ diameter with film thickness $0.25 \mu \mathrm{m}$ ) (Restek, UK). Helium was used as the carrier gas at constant flow rate of $25 \mathrm{~cm} / \mathrm{s}$. The initial oven temperature was held at $60^{\circ} \mathrm{C}$ for $1 \mathrm{~min}$ and ramped up at $10^{\circ} \mathrm{C} / \mathrm{min}$ to $300^{\circ} \mathrm{C}$, and then held for $10 \mathrm{~min}$ at the final temperature, bringing the total analysis time of $35 \mathrm{~min}$. Injection of sample (1 $\mu \mathrm{L}$ ) was made using the splitless mode at $260^{\circ} \mathrm{C}$. The scanning range was from 30-550 amu. The transfer line, the ion source and the quadrupole temperatures of the MS were set at $305^{\circ} \mathrm{C}, 230^{\circ} \mathrm{C}$ and $150^{\circ} \mathrm{C}$, respectively. All the parameters reported here were in accordance with that of the CHAMP method indicated by the previous researchers (Andersson et al. 2007b).

\section{IMPURITY PROFILING}

Data obtained from the total ion chromatogram (TIC) profiles were compared across the samples in the first instances. Impurities peaks were integrated for normalisation against the eicosane (C20) internal standard peak area. Identifications of the peaks were made using the National Institute of Standards and Technology (NIST) mass spectral database (version 2.0f) (NIST 2008) available in the GC-MS system and also using previous literatures (Allan \& Ely 2011; Andersson et al. 2007a; Bachs \& Woo 2007; Cole 2003; Inohue et al. 2008; Kunalan et al. 2009; Puthaviriyakorn et al. 2002; Qi et al. 2006; Verweij 1989).

\section{RESULTS AND DISCUSSION}

The harmonised method showed chromatographic profiles (Figures $4 \& 5$ ) of the drugs samples, showing the active compounds as well as the impurities. In forensic drug profiling, identification of compounds especially the target impurities is important for determination of possible route of synthesis. Identification based on the mass spectral data showed that amphetamine can be identified at retention time $(\mathrm{t})$ of approximately $17.5 \mathrm{~min}$, while methamphetamine eluted at much earlier interval (at approximately 8.7 min). The \% RSD values from the triplicate analyses of the amphetamine and methamphetamine samples ranged between $7.4-8.9 \%$ and $6.2-8.4 \%$, indicating good reproducibility of the analytical method.

The results in Figures 4 and 5 illustrate the ability of the CHAMP method in detecting amphetamine and methamphetamine at retention time $\left(\mathrm{t}_{\mathrm{r}}\right)$ of approximately 17.5 and $8.73 \mathrm{~min}$, respectively. In addition, impurities in the amphetamine samples remained at considerably low concentrations due to the low abundance presented (Figures 4 \& 5). Evidently, all the amphetamine samples (A, B, C and D) demonstrated similar chromatographic profiles. Except for sample $\mathrm{H}$, similar chromatographic profiles were observed for the other methamphetamine samples ( $\mathrm{E}, \mathrm{F}$ and $\mathrm{G})$. This discrepancy is common in seized sample as clandestine preparation hardly exercise quality control from one batch to another (Daeid et al. 2003). In general, fewer impurities were observed for the methamphetamine samples when compared with that of the amphetamine samples. Detection of impurities in synthetic drug although highly desired by forensic analyst, can sometimes be difficult due to the complexity of the sample itself, diverse chemical reactions that take place during synthesis as well as poor quality control especially amongst clandestine laboratories. Therefore, it is highly anticipated that variations especially in terms of chemical constituents exist in the final product as well as the addition of adulterants, diluents or cutting agents to the final product prior to distribution to the end users. Such factors and variations in impurities may prove useful in providing valuable background information to the forensic scientists about the seized samples and perhaps, their origin.

Alignment of all chromatograms of the amphetamine samples A, B, C and D showed the consistent presence of 25 compounds. Further examination of the spectral data of the impurity peaks showed vital information regarding possible synthetic route of the amphetamine samples 


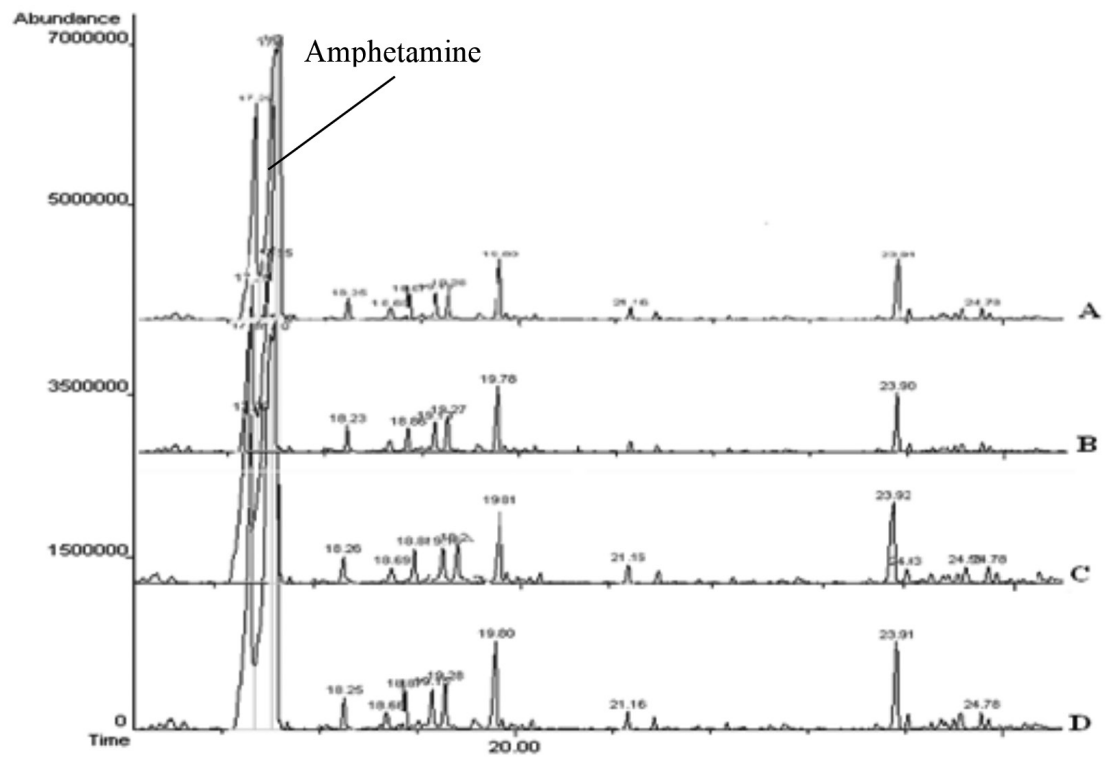

FIGURE 4. Total ion chromatograms (TIC) sections (to facilitate viewing of impurities) from the four amphetamine samples labelled as A, B, C and D

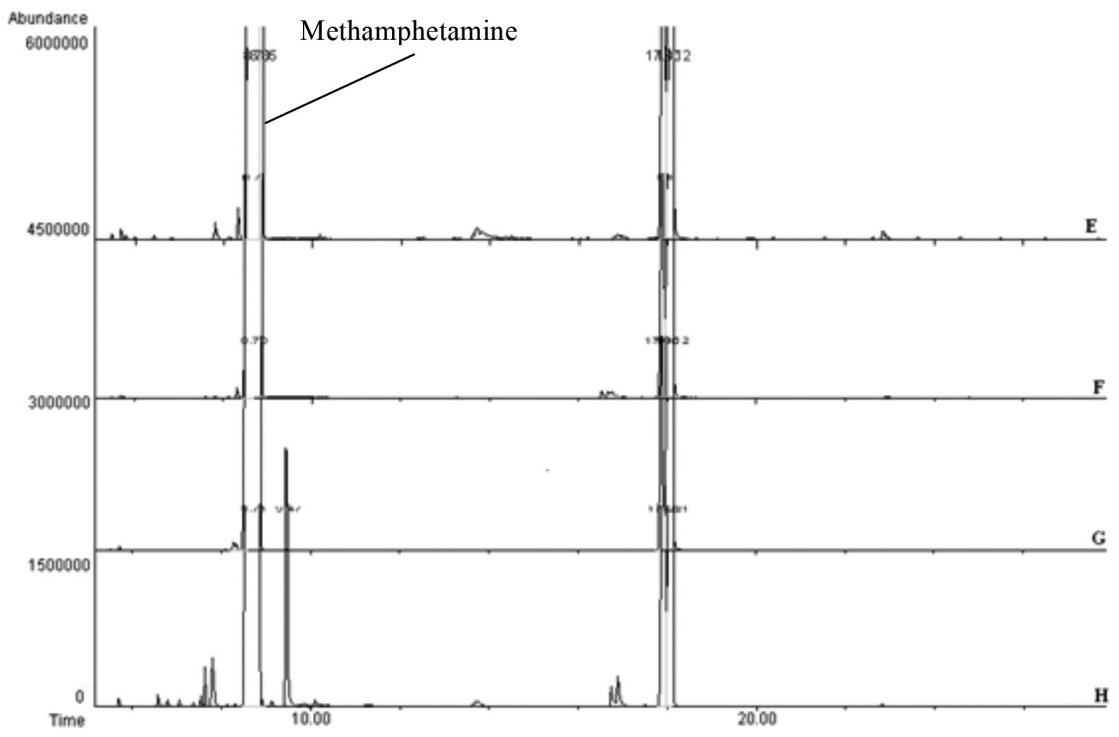

FIGURE 5. Total ion chromatograms (TIC) sections (to facilitate viewing of impurities) from the four methamphetamine samples labelled as E, F, G and $\mathrm{H}$

although not all of the impurity peaks were successfully identified. Some of the impurities were identified by comparing their mass spectral information against the hydrocarbon mass spectral database (NIST- version 2.0f) available in the GC-MS system as well as related literatures (Allan \& Ely 2011; Andersson et al. 2007a; Bachs \& Woo 2007; Cole 2003; Inohue et al. 2008; Kunalan et al. 2009; Puthaviriyakorn et al. 2002; Qi et al. 2006; Verweij 1989). Identification of these impurities has helped to point out several important markers that are specific to drugs synthesized via certain routes. The presence of Leuckart's route specific marker of methylphenylpyrimidine as suggested by Cole (2003) was also detected, eluting at approximately $12.548 \mathrm{~min}$ (Table 1 ). Other impurities viz. bis-(1 phenylisopropyl) amine, $\mathrm{N}$-formylamphetamine and $\mathrm{N}, \mathrm{N}$-di (b-phenylisopropyl) amine were also detected at retention time $\left(\mathrm{t}_{\mathrm{r}}\right)$ of approximately $17.526,21.172$ and $21.441 \mathrm{~min}$, respectively (Table1). Identification of these impurities attempted by aligning the chromatographic profiles of the amphetamine samples strongly suggested that they could be associated or had been synthesised using the Leuckart's route (Allan \& Ely 2011; Cole 2003; Verweij 1989).

Considering that in this study the impurities in all the amphetamine and methamphetamine samples were identified by comparing their mass spectral data 
TABLE 1. listed peak retention time, major mass spectrum ions and tentative identification of respective peaks from amphetamine samples

\begin{tabular}{|c|c|c|c|}
\hline $\begin{array}{c}\text { Peak } \\
\text { Number }\end{array}$ & $\begin{array}{l}\text { Retention Time } \\
\quad\left(\mathrm{t}_{\mathrm{r}}\right)(\mathrm{mins})\end{array}$ & $\begin{array}{c}\text { Major Ions } \\
(\mathrm{m} / \mathrm{z})\end{array}$ & Tentative Identification \\
\hline 1 & 12.546 & $170,102,115$ & methyl-phenylpyrimidine \\
\hline 2 & 12.946 & $118,91,72,65$ & Unknown \\
\hline 3 & 16.446 & $91,134,65,120$ & unknown \\
\hline 4 & 16.926 & $178,165,152,91$ & unknown \\
\hline 5 & 17.269 & $91,162,119,65$ & unknown \\
\hline 6 & 17.526 & $162,91,119,65$ & bis-(1 phynelisopropyl)amine \\
\hline 7 & 17.652 & $91,134,65,117$ & unknown \\
\hline 8 & 18.252 & $179,165,115,91$ & unknown \\
\hline 9 & 18.686 & $160,91,143,128$ & unknown \\
\hline 10 & 18.880 & $160,91,143,128$ & unknown \\
\hline 11 & 19.149 & $143,160,91,128$ & unknown \\
\hline 12 & 19.275 & $143,160,91,128$ & unknown \\
\hline 13 & 19.795 & $120,91,115,103$ & unknown \\
\hline 14 & 20.172 & $258,244,91,115$ & unknown \\
\hline 15 & 21.172 & $91,190,119,65,162$ & $\mathrm{~N}$-formylamphetamine \\
\hline 16 & 21.441 & $91,190,119,65$ & N,N-di ( $\beta$-phenylisopropyl)amines \\
\hline 17 & 22.184 & $118,179,91,165$ & unknown \\
\hline 18 & 22.624 & $91,120,143,115,128$ & unknown \\
\hline 19 & 22.807 & $149,91,167$ & unknown \\
\hline 20 & 23.893 & $250,70,91,117,179$ & unknown \\
\hline 21 & 24.024 & $250,91,70,115,179$ & unknown \\
\hline 22 & 24.390 & $186,91,143,115,65,168$ & unknown \\
\hline 23 & 24.779 & $91,115,128,143$ & unknown \\
\hline 24 & 24.850 & $276,91,115,65,128$ & unknown \\
\hline 25 & 25.385 & $91,215,115,77,65$ & unknown \\
\hline
\end{tabular}

against previously published literatures (Allan \& Ely 2011; Andersson et al. 2007a; Cole 2003; Bachs \& Woo 2007; Inohue et al. 2008; Kunalan et al. 2009; Puthaviriyakorn et al. 2002; Qi et al. 2006; Verweij 1989) and hydrocarbon database alone, without suitable comparisons with that of commercial pure standards (which are rarely available from commercial suppliers), the identification attempted may prove to be tentative. In this context it is pertinent to indicate here that this approach of tentative identification has been generally gaining acceptance within the body of literature (Bachs \& Woo 2007; Inohue et al. 2008; Kunalan et al. 2009; Puthaviriyakorn et al. 2002; Qi et al. 2007, 2006). The chromatographic profiles of the methamphetamine samples (Figure 5) were evidently 'cleaner' with low abundance of impurities (Table 2) when compared to that of the amphetamine samples. Interestingly, P2P was identified in the samples at retention time $\left(\mathrm{t}_{\mathrm{r}}\right)$ approximately $10.552 \mathrm{~min}$, suggesting that the samples could have been synthesised via Leuckart's, nitrostyrene, cold method or reductive amination routes. This was in agreement with the findings reported by Verweij (1989) that the reductive amination synthesis would lead to lesser with P2P being its specific impurity. Later study (Kunalan et al. 2009) further reaffirmed that P2P was the only route specific impurity for methamphetamine of reductive amination synthesis when acidic extraction was performed onto the drug. Since indication on the presence of $\mathrm{P} 2 \mathrm{P}$ when basic extraction is performed onto these drugs remains unreported, suitable inference on the possible synthetic route for sample $F$ and $G$ could not be attempted. As these were clandestine preparations, many factors (e.g. variations during production, purity of the chemicals and also human skills) may contribute to the observed inconsistencies of the impurities (Daeid et al. 2003). Therefore, further studies involving larger sample sizes as well as geographical locations acquire forensic significance. 
TABLE 2. Listed peak retention time, major mass spectrum ions and tentative identification of respective peaks from methamphetamine samples

\begin{tabular}{cccl}
\hline Peak Number & $\begin{array}{c}\text { RetentionTime }\left(\mathrm{t}_{\mathrm{r}}\right) \\
(\mathrm{mins})\end{array}$ & $\begin{array}{c}\text { Major Ions } \\
(\mathrm{m} / \mathrm{z})\end{array}$ & Tentative Identification \\
\hline 1 & 5.677 & $77,51,105,106$ & Unknown \\
2 & 7.077 & $79,77,51,106,91$ & Unknown \\
3 & 7.334 & $105,77,51,136$ & Unknown \\
4 & 9.546 & $72,91,65,77,148$ & Unknown \\
5 & 10.552 & $91,132,65,51$ & P2P \\
6 & 12.078 & $118,117,91,58,191$ & Unknown \\
7 & 16.313 & $132,91,118,77$ & Unknown \\
8 & 18.651 & $91,148,190,119,77$ & Unknown \\
9 & 19.457 & $105,77,162,91$ & Unknown \\
10 & 19.954 & $160,91,77,105$ & Unknown \\
11 & 22.017 & $149,57,167,71$ & Unknown \\
\hline
\end{tabular}

\section{CONCLUSION}

The use of harmonised methods for analysing these two types of phenethyl amine drugs i.e. amphetamine and methamphetamine prove feasible. Identification of route specific impurities in the amphetamine samples suggested that $\mathrm{P} 2 \mathrm{P}$ was used as the starting material and the samples were synthesised by the Leuckart's route. Considering the similarities in the chromatographic profiles of samples A, $\mathrm{B}, \mathrm{C}$ and $\mathrm{D}$ and the fact that 4-methyl-5-phenylpyrimidine, i.e. a specific impurity for Leuckart's route was found in all amphetamine samples, the possibility that the samples originated from the same source could not be ruled out. Although no conclusive identification could be made out for impurities in the methamphetamine samples, the presence of $\mathrm{P} 2 \mathrm{P}$ is suggestive towards the possibility of synthetic route being either Leuckart's, nitrostyrene or aminative reduction pathway. This study demonstrates that impurity profiling of illicit drugs with regard to synthesis route is useful to establish possible connections between drug seizures. Further studies on similar samples profile using amphetamine harmonised and other practised methods may be useful for comparing the effectiveness of extraction.

\section{ACKNOWLEDGEMENTS}

The authors would like to acknowledge the Ministry of Higher Education, Malaysia for the fellowship granted and would also like to extend gratitude to the Centre for Forensic Science, Strathclyde University, Scotland, especially to Prof. N.N. Daeid and to Dr. V. Kunalan of Jabatan Kimia Malaysia, Petaling Jaya for their assistance.

\section{REFERENCES}

Aalberg, L., Andersson, K., Bertler, C., Cole, M.D., Finnon, Y., Huizer, H., Jalava, K., Kaa, E., Lock, E., Lopes, A., Meer, A.P.-v. d., Sippola, E. \& Dahlén, J. 2005a. Development of a harmonised method for the profiling of amphetamines: II. Stability of impurities in organic solvents. Forensic Science International 149(2-3): 231-241.

Aalberg, L., Andersson, K., Bertler, C., Boren, H., Cole, M.D., Dahlen, J., Finnon, Y., Huizer, H., Jalava, K., Kaa, E., Lock, E., Lopes, A., van der Meer, A.P. \& Sippola, E. 2005b. Development of a harmonised method for the profiling of amphetamines, I. Synthesis of standards and compilation of analytical data. Forensic Science International 149(2-3): 219-229.

Abdullah, A.F.L., Haw, C.K., MatDesa, W., Sulaiman, M., Hamdan, R. \& Kunalan, V. 2014. Clandestine drug laboratory: Emergence, types, factors and problems. Health and the Environment Journal 5(2): 11-27.

Allan, A. \& Ely, R. 2011. In Crime Scene, Northwestern Association of Forensic Scientist (NWAFS) Newsletter Vol. 37, Washington, USA. pp. 15-25.

Allen,A.\& Cantrell, T.S. 1989. Synthetic reductions in clandestine amphetamines and methamphetamines laboratories: A review. Forensic Science International 42(1): 183-199.

Andersson, K., Jalava, K., Lock, E., Finnon, Y., Huizer, H., Kaa, E., Lopes, A., van der Meer, A.P., Cole, M.D., Dahlén, J. \& Sippola, E. 2007a. Development of a harmonised method for the profiling of amphetamines: III. Development of the gas chromatographic method. Forensic Science International 169(1): 50-63.

Andersson, K., Jalava, K., Lock, E., Huizer, H., Kaa, E., Lopes, A., van der Meer, A.P., Cole, M.D., Dahlén, J. \& Sippola, E. 2007b. Development of a harmonised method for the profiling of amphetamines: IV. Optimisation of sample preparation. Forensic Science International 169(1): 64-76.

Andersson, K., Lock, E., Jalava, K., Huizer, H., Jonson, S., Kaa, E., Lopes, A., van der Meer, A.P., Sippola, E., Dujourdy, L. \& Dahlén, J. 2007c. Development of a harmonised method for the profiling of amphetamines VI: Evaluation of methods for comparison of amphetamine. Forensic Science International 169(1): 86-99.

Bachs, S. \& Woo, F. 2007. A detailed mechanistic fragmentation analysis of methamphetamine and select regioisomers by $\mathrm{GC} /$ MS. Journal of Forensic Sciences 52(2): 308-319. 
Baharudin, A., Anuar, L., Saini, S., Bakar, O.C., Razali, R. \& Jaafar, N.R.N. 2013. Psychiatric comorbidity among community-based, treatment seeking opioid dependents in Klang Valley. Sains Malaysiana 42(3): 417-421.

Ballany, J., Caddy, B., Cole, M.D., Finnon, Y., Aalberg, L. \& Janhunen, K. 2001. Developement of a harmonised panEuropean method for the profiling of amphetamines. Science and Justice 41(3): 193-196.

Cole, M.D. 2003. The Analysis of Controlled Substances. West Sussex: John Wiley \& Sons.

Daeid, N.N., Cresswell, S. \& Ismail, D. 2003. Variations in the organic impurity profile in Leuckart synthesised amphetamine sulphate made by the same chemist. Forensic Science International 136(suppl. 1): 89-90.

Hamdan, R., Hassan, N.F.N., Desa, W.N.S.M., Kunalan, V., Sulaiman, M. \& Abdullah, A.F.L. 2015. Characterisation of seized clandestine methamphetamine in Malaysia. Malaysian Journal of Forensic Sciences 6(1): 20-29.

Inohue, H., Iwata, Y.T. \& Kuyama, K. 2008. Characterization and profiling of methamphetamine seizures. Journal of Health and Sciences 54(6): 615-622.

Isa, M.F.M., Guan, N.C., Rashid, R.A., Habil, M.H., Sidi, H., Said, M.A.\& Sulaiman, A.H. 2013. Sexual behaviour among male methamphetamine and heroin dependents in selected areas in Malaysia. Sains Malaysiana 42(12): 1819-1826.

Kunalan, V., NicDaeid, N., Kerr, W.J., Buchanan, H.A.S. \& McPherson, A.R. 2009. Characterization of route specific impurities found in methamphetamine synthesized by the Leuckart route and reductive amination methods. Analytical Chemistry 81(17): 7342-7348.

Lock, E., Aalberg, L., Andersson, K., Dahlén, J., Cole, M.D., Finnon, Y., Huizer, H., Jalava, K., Kaa, E., Lopes, A., van der Meer,A.P. \& Sippola, E. 2007. Development of a harmonised method for the profiling of amphetamines V: Determination of the variability of the optimised method. Forensic Science International 169(1): 77-85.

NIST. 2008. Mass spectral ibrary (NIST 08) and NIST mass spectral earch programe (version 2.0f).

Power, J.D., O’Brien, J., Talbot, B., Barry, M. \& Kavanagh, P. 2014. The identification of an impurity product, 4,6-dimethyl3,5-diphenylpyridin-2-one in an amphetamine importation seizure, a potential route specific by-product for amphetamine synthesized by the APAAN to P2P, Leuckart route. Forensic Science International 241: e13-e19.
Puthaviriyakorn, N., Siriviriyasomboon, J., Phorachata, W., Pan-ox, W., Sasaki, T. \& K.Tanaka (2002). Identification of impurities and statistical classification of methamphetamine tablets (Ya-Ba) seized in Thailand. Forensic Science International 1(2): 105-113.

Qi, Y., Evans, I.D. \& McCluskey, A. 2006. Australian federal police seizures of illicit crystalline methamphetamine ('ice') 1998-2002: Impurity analysis. Forensic Science International 164(2-3): 201-210

Qi, Y.,Evans, I.D. \& McCluskey, A. 2007. New impurity profiles of recent Australian imported 'ice': methamphetamine impurity profiling and the identification of (pseudo)ephedrine and Leuckart specific marker compounds. Forensic Science International 169: 173-180.

Stojanovska, N., Fu, S., Tahtouh, M., Kelly, T., Beavis, A. \& Kirkbride, K.P. 2013. A review of impurity profiling and synthetic route of manufacture of methylamphetamine, 3,4-methylenedioxymethylamphetamine, amphetamine, dimethylamphetamine and p-methoxyamphetamine Forensic Science International 224(1-3): 8-26.

United Nations Office on Drugs and Crime (UNODC), United Nations. 2014. New York.

Verweij, A.M.A. 1989. Impurities in illicit drug preparations: Amphetamine and Methamphetamines. Forensic Science Review 1(1): 1-11.

Forensic Science Programme, School of Health Sciences Universiti Sains Malaysia

16150 Kubang Kerian, Kelantan Darul Naim

Malaysia

*Corresponding author; email: wannurs@usm.my

Received: 23 February 2016

Accepted: 9 May 2016 